\title{
Respon Guru SD melalui Training of Teacher untuk Meningkatkan Kecapakan Matematis di Era Revolusi 4.0
}

\author{
Mira Nurhayati ${ }^{1}$, Aldi Putra Wijaya ${ }^{2}$, Fitri Rahmadhani ${ }^{3}$, Gresilia Situmorang ${ }^{4}$, \\ Nizzah Aulia Ahsanah Mukarromah ${ }^{5}$, Zulkardi ${ }^{6}$, Novika Sukmaningthias ${ }^{7}$, Zuli \\ Nuraeni* \\ ${ }^{12345}$ Universitas Sriwijaya,Indralaya \\ ${ }^{678}$ Universitas Sriwijaya,Palembang \\ Penulis Korespondensi: zulinuraeni@fkip.unsri.ac.id
}

\begin{abstract}
This study aims to determine the response of elementary school teachers to the Training of Teacher activities to improve Mathematical Skills in the Revolutionary Era 4.0. This type of research is a qualitative descriptive study involving as many as 6 teachers at SD Negeri 7 Lawang Kidul as the subject. The data collection technique in this study was a questionnaire with open answers which were distributed after training to teachers for 6 days. The questionnaire contained reflections on the training that had been carried out previously. The data that has been obtained is then processed and analyzed in a NonStatistical Qualitative manner, that is, without any statistical calculations, then the results in this study will be described through sentences where conclusions will be drawn. The results of the research from the implementation of the Training of Teachers (ToT) to improve the mathematical skills of teachers in the Revolutionary Era 4.0. seen from the data analysis and discussion, it was found that the teacher had obtained some information about the skills needed in the era of the industrial revolution 4.0 including learning mathematics with practice, using various learning media, and the knowledge that when a mathematics teacher teaches it must be a fun teacher. and can explain mathematics learning material in an interesting way.
\end{abstract}

Keywords: Mathematics skill, Response, Training of Teachers

Penelitian ini bertujuan untuk mengetahui Respon Guru SD terhadap kegiatan Training of Teacher untuk meningkatkan Kecapakan Matematis di Era Revolusi 4.0. Jenis penelitian ini adalah penelitian Deskriptif Kualitatif dengan melibatkan subjek sebanyak 6 guru SD Negeri 7 Lawang Kidul. Teknik pengumpulan data pada penelitian ini yaitu angket dengan jawaban terbuka yang disebarkan setelah dilakukan pelatihan kepada guru selama 6 hari. Pada angket memuat perihal refleksi dari pelatihan yang telah dilakukan sebelumnya. Data-data yang telah didapat kemudian diolah dan dianalisis secara Kualitatif Non Statistik yaitu, tanpa adanya perhitungan statistik, lalu hasil pada penelitian ini akan dideskripsikan melalui kalimat yang akan ditarik kesimpulannya. Hasil penelitian dari dilaksanakannya Training of Teachers (ToT) untuk meningkatkan kecakapan matematis guru di Era Revolusi 4.0. diihat dari data analisis dan pembahasan diperoleh bahwa guru telah mendapatkan beberapa informasi mengenai kecakapan yang diperlukan pada era revolusi industri 4.0 diantaranya belajar matematika dengan praktik, menggunakan media pembelajaran yang bervariasi, dan pengetahuan bahwa ketika seorang guru matematika yang mengajar itu harus menjadi seorang guru yang menyenangkan dan bisa menjelaskan materi pembelajaran matematika dengan cara yang menarik.

Kata kunci: Kecakapan Matematika, Respon, Training of Teachers

\section{PENDAHULUAN}

Pendidikan merupakan jembatan bagi seseorang supaya dapat meningkatkan kualitas hidupnya secara teknis operasional yang dapat dilakukan melalui pembelajaran (Shaumi, 2015). Guru merupakan salah satu unsur paling penting dalam pendidikan tersebut. Guru yang berkualitas sangat dibutuhkan untuk memberikan pendidikan 
nasional yang baik supaya mampu menjadi dasar pijakan atau sebagai tumpuan selama proses pendidikan berlangsung.

Guru mempunyai fungsi dan peran yang sangat strategis dalam pembangunan bidang pendidikan (Miarso, 2008). Tugas seorang guru selain mengajar, melatih, mendidik, dan mengevaluasi setiap siswa adalah mengembangkan serta meneruskan nilai-nilai kehidupan kepada siswanya sehingga siswa dapat mengembangkan keterampilan dan menerapkannya dalam kehidupan dimasa depan (Somantri, 2021). Akan menjadi sangat ideal apabila setiap guru di Indonesia mempunyai kemampuan teknologi mendidik tersebut selama mendidik siswanya.

Untuk mendukung profesionalisme seorang guru, maka sangat dibutuhkan penguasaan terhadap teknologi dan informasi oleh tenaga pendidik (Pribowo, 2017). Hal ini dikarenakan sekarang ini siswa - siswi Sekolah Dasar sudah mampu untuk menggunakan teknologi, tentunya juga memberikan dampak terhadap perubahan proses pembelajaran seperti penggunaan metode, strategi, media pembelajaran, daan proses evaluasi pembelajaran. Dengan begitu guru sebagai tenaga pendidik juga harus dapat beradaptasi dan meningkatkan kualitas pembelajaran.

Pembelajaran matematika menjadi pembelajaran yang sangat menarik dan menantang jika pembelajarannya menggunakan teknologi sehingga membuat siswa siswi dapat lebih kreatif dalam menyelesaikan permasalahan matematika. Kompetensi matematika dari jenjang sekolah dasar menjadi modal awal sebelum memasuki nalar kreatif dan sintesa. Karena tidak mungkin rasanya kreativitas dan sintesa yang produktif akan tumbuh jika penalaran matematika dapa jenjang sekolah dasar saja masih buruk. Jika hal seperti ini tidak segera ditangani dengan serius makan akan berdampak besar dikemudian hari, yang mana pada tahun 2045 nanti tepat usia Indonesia ke 100 tahun dengan PDB mencapai peringkat ke-4 sedunia namun kompetensi matematika di jenjang sekolah dasar saja masih rendah, akan sulit untuk membuat SDM kita dapat bersaing secara gelobal dikemudian hari.

Penggunaan teknologi digital merupakan salah satu dari beragam issue yang bisa menjadi peluang untk meningkatkan mutu dan kualitas pembelajaran matematika pada Sekolah Dasar di era revolusi industri 4.0 (Putra, 2019). Hadirnya teknologi dalam pembelajaran matematika menjadi salah satu strategi yang bisa digunakan untuk membuat konsep matematika yang abstrak menjadi lebih konkrit (Sintawati \& Indriani, 2019). Apalagi penerapan penggunaan teknologi pada para siswa Sekolah Dasar tentunya akan memberikan kesan yang menyenangkan dan juga bermakna bagi para siswa jenjang sekolah dasar, karena penggunaan teknologi dapat membantu meningkatkan motivasi belajar, proses pembelajaran lebih visual, konkrit, menyenangkan, dan menarik. Berdasarkan Permendikbud no 22 tahun 2016 dalam standar proses pada prinsip pembelajaran yang digunakan adalah guru harus dapat menerapkan penggunaan teknologi informasi dan komunikasi secara teritegrasi, sistematis, dan efektif untuk meningkatkan efisiensi pembelajaran.

Pada sekarang ini teknologi sudah menjadi suatu kebutuhan primer diberbagai bidang terutama pada bidang pendidikan. Diciptakannya teknologi ini tujuannya untuk 
memudahkan pekerjaan manusia (Syahrudin, 2020). Menemukan informasi maupun ilmu pengetahuan mungkin sudah sangat mudah dilakukan melalui Google. Namun, teknologi pencari yang populer itu tidak bisa membentuk nilai karakter kepada anak didik. Disinilah peran guru menjadi sangat penting (Wati \& Kamila 2019).

Seiring pesatnya perkembangan zaman dan teknologi mengharuskan lembaga pendidikan dan tenaga pendidik dalam hal ini guru menghadapi tuntutan yang semangkin berat, lembaga pendidikan dan guru dituntut untuk mempersiapkan siswa supaya dapat menghadapi berbagai dinamika perkembangan ilmu pengetahuhuan dan teknologi serta perubahan aspek nilai moral yang terjadi dalam kehidupan masyarakat (Suparto, 2016). Adanya revolusi industri generasi keempat atau bisa juga disebut revolusi industri 4.0 ini merupakan dampak dari perkembangan ilmu pengetahuan dan teknologi yang semakin pesat (Sintawati \& Indriani, 2019).

Guru sebagai tenaga pendidik harus lebih cerdas dan pintar dalam menyikapi perkembangan teknologi yang semakin pesat ini dibandingkan siswa -siswinya. Jangan sampai seorang tenaga pendidik tidak menguasai teknologi, mengingat siswa -siswinya lebih akrab dengan dunia teknologi dan komunikasi. (Astini, 2019). Jika hal seperti ini terjadi dapat menjadi maka bomerang yang akan mempengaruhi profesionalitas seorang tenaga pendidik. Sehingga perlunya pelatihan terhadap para tenaga pendidik supaya dapat menguasai teknologi salah satunya melalui kegiatan training of teacher (ToT).

Berdasarkan uraian diatas dengan hadirnya era revolusi industri 4.0 pentingnya peningkatan kualitas atau profesionalisme seorang guru dalam meningkatkan kualitas Sumber daya Manusia melalui proses pendidikan mulai dari sekolah dasar hingga ke janjang selanjutnya yang lebih tinggi yang merupakan kunci untuk dapat mengikuti perkembangan Revolusi Industri 4.0 (Lase, 2014). Sehingga tujuan dari penulis menulis artikel ini untuk mengetahui respon Guru SD melalui kegiatan Training of Teacher untuk Meningkatkan Kecapakan Matematis di Era Revolusi 4.0.

\section{METODE}

Jenis pada penelitian ini adalah penelitian deskriptif kualitatif. Menurut KBBI, penelitian adalah suatu kegiatan pengumpulan, analisis, serta penyajian data yang dilaksanakan secara sistematis dan objektif untuk memecahkan suatu persoalan atau menguji suatu hipotesis untuk mengembangkan prinsip-prinsip umum. Sedangkan deskriptif adalah sifat deskripsi dan menggambarkan apa adanya. Sehingga metode deskriptif adalah metode penelitian yang dilakukan dengan cara menggambarkan objek penelitian secara apa adanya untuk memecahkan suatu persoalan. Kualitatif adalah suatu tidakan berdasarkan mutu. Pada penelitian ini, peneliti ingin memperoleh data yang bentuknya berupa kalimat yang akan diambil kesimpulannya.

Subjek pada penelitian ini adalah 6 orang guru SDN 07 Lawang Kidul. Teknik pengumpulan data dilakukan dengan cara menyebarkan angket setelah dilakukan pelatihan kepada guru tersebut selama 6 hari. Angket yang digunakan pada penelitian ini merupakan angket dengan jawaban terbuka. Pada angket memuat perihal refleksi 
dari pelatihan yang telah dilakukan sebelumnya. Pada angket tersebut para guru yang telah mengikuti kegiatan Training of Teacher akan menyampaikan apa saja yang dirasakan dan didapatkan saat melakukan kegiatan tersebut.

Data-data yang telah didapat kemudian diolah dan dianalisis secara kualitatif non statistik yaitu, tanpa adanya perhitungan statistik. Hasil pada penelitian ini akan dideskripsikan melalui kalimat yang akan ditarik kesimpulannya.

Tujuan penelitian ini adalah untuk mengetahui respon Guru SD melalui Training of Teacher untuk meningkatkan kecapakan matematis di Era Revolusi 4.0.

\section{HASIL DAN PEMBAHASAN}

Berdasarkan hasil angket tentang pengalaman belajar guru SD Negeri 7 Lawang Kidul diperoleh bahwa pengalaman selama belajar matematika yang menyenangkan diantaranya belajar matematika dengan praktik,menggunakan media pembelajaran yang bervariasi, dan ketika seorang guru matematika yang mengajar itu adalah seorang guru yang menyenangkan dan bisa menjelaskan materi pembelajaran matematika dengan cara yang menarik. Sehingga, berdasarkan hasil tersebut dilaksanakanlah Training of Teachers (ToT) untuk meningkatkan kecakapan guru dalam mendidik siswa SD di era revolusi industri 4.0 .

Kegiatan pelatihan guru SD ini dilaksanakan selama 6 pertemuan melalui zoom meeting, dan pengimplementasiannya dilaksanakan selama 3 bulan selanjutnya yaitu oktober, november, dan desember. Adapun tujuan dari kegiatan pelatihan guru ini diantaranya 1) agar guru memiliki gagasan tentang penerapan pemecahan masalah, koneksi, representasi, komunikasi , dan penalaran dalam perancangan maupun aplikasi kegiatan belajar dan mengajar. 2) agar guru memiliki gagasan tentang pendekatan konkret-gambar-abstrak dalam perancangan maupun aplikasi kegiatan belajar dan mengajar matematika. 3) agar guru memiliki gagasan tentang pendekatan kontekstual dalam perancangan maupun aplikasi kegiatan belajar dan mengajar matematika, dan 4) agar guru menunjukan minat untuk melakukan perubahan pembelajaran di kelasnya serta terdapat diseminasi gagasan kepada rekan sebaya melalui berbagai media.

Kegiatan pelatihan guru SD ini dilaksanakan selama enam pertemuan yang meliputi prinsip-prinsip belajar dan mengajar matematika, belajar dan mengajar bilangan, belajar dan mengajar geometri, belajar dan mengajar pengukuran, belajar mengajar statistika dan probabilitas, dan asesmen di kelas matematika. Kegiatan pelatihan guru ini memfokuskan penggunaan pendekatan KGA atau CPA dalam pembelajaran matematika. Pendekatan CPA ini juga sering disebut sebagai pendekatan Concrete-Representational-Abstract (CRA) atau pendekatan Concrete-SemiconcreteAbstract (CSA). Pendekatan Concrete-Pictorial-Abstract (CPA) secara umum terdiri dari tiga langkah, yaitu: concrete yang merupakan langkah khusus yang digunakan siswa dalam fase menggambar setelah mereka menyelesaikan masalah matematika menggunakan benda konkret atau benda-benda nyata, kemudian pada langkahpictorial siswa menggunakan benda melalui perwakilan gambar dari manipulasi benda konkret, dan pada langkah abstract siswa menggunakan simbol-simbol atau notasi-notasi 
abstrak. Kegiatan ini memfokuskan pendekatan KGA karena anak-anak usia sekolah dasar berada pada tahap manipulasi tertentu, dan anak pada tahap ini sudah lebih jauh dapat berpikir atau memanipulasi benda-benda nyata daripada anak pada tahap preoperasional.

Pada kegiatan pelatihan, guru dilatih bagaimana memecahkan suatu masalah menggunakan alat peraga seperti masalah kepekaan bilangan menggunakan gambar ikan cikalang, masalah nilai tempat menggunakan alat peraga satuan, puluhan, dan ratusan, pemecahan masalah G.Polya menggunakan pita dan membuat wadah penampungan, masalah penalaran spasial menggunakan tangram, aktivitas Van Hiele menggunakan tusuk gigi dan sedotan, pengkuran melalui benda-benda di sekitar, probabilitas menggunakan pewarnaan kapal dan dadu, dan masalah statistika menggunakan pita, kartu, dan kancing pakaian.

Setelah dilaksanakan pelatihan guru melalui Program Gerakan Berantas Buta Matematika selama beberapa hari kemudian dilakukan pengambilan data dengan cara menyebarkan angket dengan jawaban terbuka yang diberikan kepada 6 orang guru SD 7 didapatkan hasil berupa tabel berikut:

\section{Tabel 1. Hasil Angket}

\begin{tabular}{|c|c|}
\hline Nama guru & Refleksi setelah melaksanakan pelatihan \\
\hline Guru A & $\begin{array}{l}\text { Dari kegiatan ini saya mendapatkan hal-hal baru, menarik dan menyenangkan seperti } \\
\text { pada pembelajaran diantaranya cara membentuk segitiga dari tusuk dan lainnya. } \\
\text { Hasil yang saya peroleh dari pelatihan ini akan saya terapkan pada proses } \\
\text { pembelajaran di kelas. }\end{array}$ \\
\hline Guru B & $\begin{array}{l}\text { Setelah mengikuti kegiatan hari ini, sangat menyenangkan dan dapat ilmu baru tetang } \\
\text { cara penyampaian pembelajaran dengan cara yang mudah di pelajari siswa. Selain itu } \\
\text { juga diberitahukan beberapa media pembelajaran yang sesuia dengan keadaan saat } \\
\text { ini. }\end{array}$ \\
\hline Guru C & $\begin{array}{l}\text { Setelah mengikuti tot saya banyak belajar bagai mana cara mengajarkan matematika } \\
\text { kepada peserta didim dengan cara yang menyenangkan sehingga pelajaran } \\
\text { matematika menjadi menyenangkan. }\end{array}$ \\
\hline Guru D & $\begin{array}{l}\text { Pengalaman baru yang saya dapatkan dalam kegiatan ini } \\
\text { Saya mendapatkan cara baru bagaimana cara belajar matematika yang } \\
\text { menyenangkan. }\end{array}$ \\
\hline Guru E & $\begin{array}{l}\text { Setelah mengikuti kegiatan hari ini banyak sekali ilmu yang didapat. } \\
\text { Pada pembelajaran tentang assesmen ini membuat saya lebih tahu setiap } \\
\text { penilaian,penilaian of learning, for learning.semoga dgn mudah dapat saya terapkan } \\
\text { kepada siswa disekolah kami }\end{array}$ \\
\hline Guru F & $\begin{array}{l}\text { Setelah mengikuti pembelajaran ini banyak ilmu yg saya dapatkan dan metode } \\
\text { pembelajaran yg selama ini belum pernah saya dapatkan. }\end{array}$ \\
\hline
\end{tabular}

Dari tabel di atas dapat diketahui bahwa melalui pelatihan guru pada Program Gerakan Berantas Buta Matematika ini banyak pengalaman baru yang diperoleh para 
guru yang dapat diterapkan pada pembeljaran matematika. Dengan pelatihan ini, para guru bisa merancang pembelajaran yang menyenangkan dan menggunakan bantuan teknologi di dalam proses pembelajaran.

Melalui kegiatan pelatihan guru ini ada beberapa kecakapan matematika pada era revolusi industri 4.0 diantaranya yang pertama guru memiliki gagasan tentang penerapan pemecahan masalah, koneksi, representasi, komunikasi, dan penalaran dalam perancangan maupun aplikasi kegiatan belajar dan mengajar, hal ini dapat kita lihat melalui refleksi yang disampaikan oleh para guru setelah kegiatan 6 hari tersebut. Yang kedua, agar guru memiliki gagasan tentang pendekatan konkret-gambar-abstrak dalam perancangan maupun aplikasi kegiatan belajar dan mengajar matematika. Hal ini dapat kita rasakan saat guru memilih media pembelajaran yang tepat untuk pembelajaran agar pembelajaran berjalan dengan lancar dan menyenangkan. Ketiga, agar guru memiliki gagasan tentang pendekatan kontekstual dalam perancangan maupun aplikasi kegiatan belajar dan mengajar matematika. Yang keempat agar guru menunjukan minat untuk melakukan perubahan pembelajaran di kelasnya serta terdapat diseminasi gagasan kepada rekan sebaya melalui berbagai media. Kecakapan yang ingin dicapai pada pelatihan ini telah dirasakan oleh para guru.

Seperti yang disampaikan oleh Guru C , pada hari pertama dan kedua pelatihan, guru $\mathrm{C}$ mendapatkan pengalaman yang menyenangkan dari pelatihan ini ia juga bisa menerapkan penggunaan teknologi di dalam proses pembelajarannya. Seperti pada materi geometri yang didapatkan pada kegiatan hari ketiga. Di dalam pembelajarannya menggunakan bantuan aplikasi tangram. Melalui aplikasi tangram ini dapat menambah pengetahuan dalam mengajarkan geometri kepada peserta didik. Maka dari itu agar peserta didik memiliki kecakapan untuk menggunakan teknologi dalam pembelajaran maka terlebih dahulu gurunya mampu menguasai kecakapan tersebut. Lalu, guru juga memiliki gagasan tentang pendekatan konkret-gambar-abstrak dalam perancangan maupun aplikasi kegiatan belajar dan mengajar matematika. Kemudian pada hari keempat, kelima, dan keenam Guru C merasakan banyak manfaat dari kegiatan ini yang dapat diterapkan di dalam pembelajaran matematika agar lebih menyenangkan seperti penggunaan tagram.

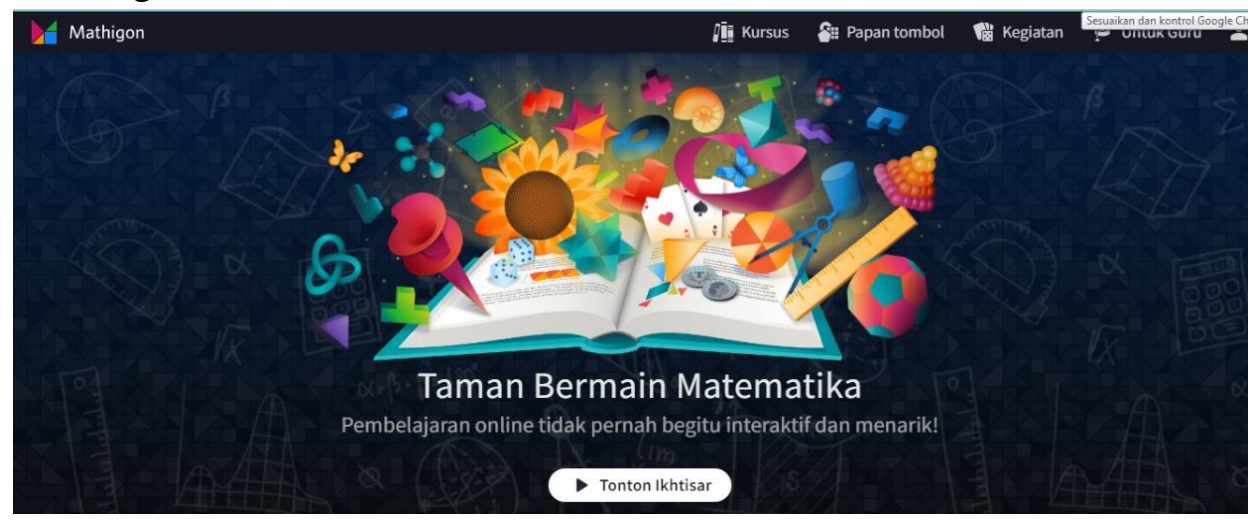

Gambar 1. Aplikasi Mathigon 
Kemudian menurut Guru A melalui pelatihan ini banyak pengalaman yang didapatkan yang bisa diterapkan pada pembelajaran siswa Sekolah Dasar yang dirasakannya pada 6 hari kegiatan. Karena seperti yang kita ketahui, pada tingkat Sekolah Dasar pembelajaran dirancang sesuai dengan apa yang ada disekitar kita. Seperti cara membentuk segitiga dari tusuk dan lainnya yang didapatkan pada hari ketiga. Di dalam pembelajaran para guru dilatih untuk dapat menggunakan barangbarang yang ada disekitar siswa untuk digunakan sebagai media pembelajaran. Hal ini dapat dilakukan seperti gambar di bawah ini. Selain itu juga, pada hari kelima materi pembelajaran hari ini adalah tentang statistika dan probabilitas. Guru A merasa sangat senang untuk materi hari ini karena tadi dalam materi probabilitas kita melakukan permainan dadu untuk menentukan peluang. Lalu pada hari keenam , pada pembelajaran kali ini,banyak sekali ilmu baru yang sudah ia dapatkan dan tentunya akan sangat bermanfaat baginya ke depannya, terutama jenis-jenis assesmen yang sudah dibahas tadi.

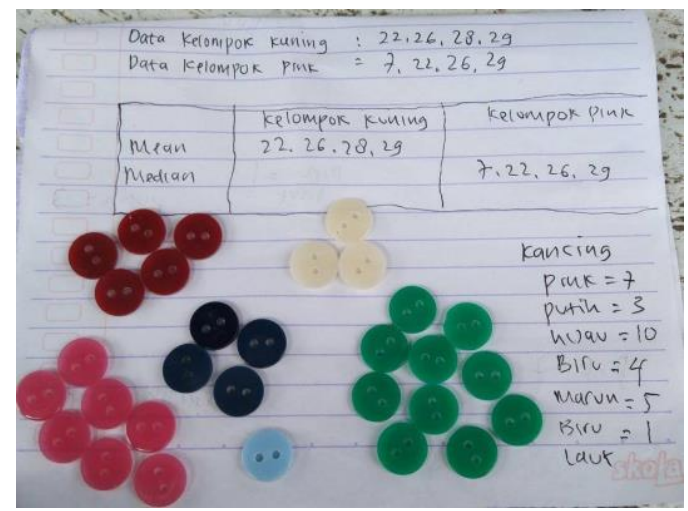

\section{Gambar 2. Pembelajaran dengan barang sekitar}

Lalu, menurut Guru D, ia berkata melalui kegiatan ini banyak hal baru yang diperoleh untuk membuat pembelajaran matematika lebih menyenangkan selama 6 hari kegaitan. Salah satunya seperti yang dapat dilihat pada gambar di bawah ini. Hak ini merupakan kegiatan yang dilakukan pada hari ketiga. Pembelajaran dirancang menggunakan kertas origami yang memiliki variasi warna. Hal ini membuat siswa akan lebih tertarik dan merasa senang. Kemudian pada hari kelima, setelah mengikuti pembelajaran ini mendapatkan ilmu baru tentang menentukan mean,median dan modus dan sangat menarik ketika mewarnai kapal dan menghitung kancing. Lalu pada hari keenam, dengan pelatihan ini banyak pengetahuan baru tentang assessment dan terima kasih telah berbagi ilmu kepada kami. 


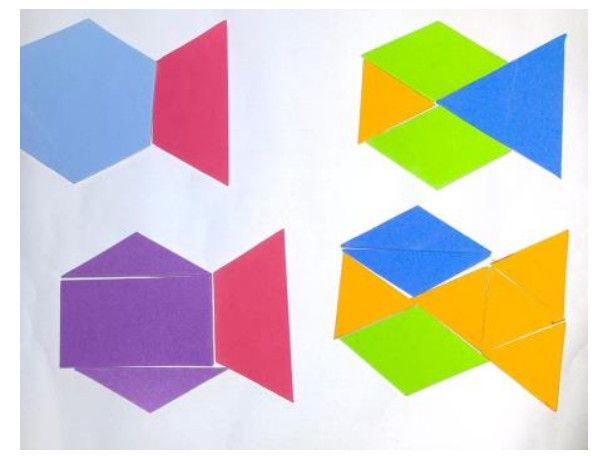

\section{Gambar 3. Pembelajaran dengan kertas origami}

Lalu Guru B menyatakan bahwa setelah mengikuti kegiatan hari ini, banyak sekali ilmu yang didapat diantara pada hari kedua yaitu kepekaan bilangan dengan menggunakan bingkai 10, yang menunjukkan kalau angka itu memiliki pasangannya masing-masing hingga membentuk angka 10. Kemudian nilai tempat, yang tidak hanya terpaku pada ratusan, puluhan dan satuan serta pemecahan masalah dengan berbagai macam metode KGA. Hal yang disampaikan oleh Guru B sesuai dengan tujuan pelatihan ini yaitu untuk menumbuhkan kecakapan guru yaitu memiliki gagasan tentang penerapan pemecahan masalah, koneksi, representasi, komunikasi , dan penalaran dalam perancangan maupun aplikasi kegiatan belajar dan mengajar.

Menurut Guru E, pengalaman matematika yang menyenangkan di dalam pembelajarannya sangat menarik dan tidak monoton dikarenakan banyak media pembelajaran yang dapat digunakan seperti kartu, puzzle, ular tangga, dan lainnya. Seperti pada hari kelima, setelah mengikuti kegiatan hari ini dapat ilmu baru tentang mean,median,modus dgn menggunakan pita sebagai alat peraga dan juga pada hari keenam, pada pembelajaran tentang assesmen ini membuat ia lebih tahu setiap penilaian, penilaian of learning, for learning serta ia berharap semoga dengan mudah dapat diterapkan kepada siswa disekolahnya.

Kemudian menurut Guru F, setelah mengikuti pembelajaran ini banyak ilmu yg saya dapatkan dan metode pembelajaran yang selama ini belum pernah saya dapatkan seperti pada hari kelima setelah mengikuti kegiatan ini, ia dapat belajar data dari pengolahan data, analiais data menentukan mean dan median. Yang sangat menarik menurutnya, ketika mewarnai kapal, menghitung kancing dan melempar dadu. Ternyata dengan kegiatan yang menyenangkan tersebut kita dapat mengumpulkan data dengan cara yang sangat menyenangkan. Maka dari kegiatan ini , Guru F mendapatkan pengalaman menyenangkan yaitu agar siswa merasa senang dalam pembelajaran maka guru hendaknya melakukan cara mengajarn yang melalui suatu pendekatan yang dapat menciptkan suasana pembelajaran yang menyenangkan.

Setelah menganalisis dari angket yang telah diberikan kepada para guru yang mengikuti pelatihan tersebut, para guru telah mendapatkan beberapa informasi mengenai kecakapan yang diperlukan para era revolusi industri 4.0 dalam mendidik siswa SD pada pembelajaran matematika. Hasil yang didapatkan oleh para guru dapat 
mereka terapkan pada pembelajaran. Melalui kegiatan ini pula diharapkan dapat menciptakan para siswa yang siap menghadapi tantangan pada era revolusi industri 4.0.

\section{SIMPULAN DAN SARAN}

Dari hasil penelitian setelah dilaksanakannya Training of Teachers (ToT), maka diperoleh hasil bahwa para guru telah mendapatkan beberapa informasi mengenai kecakapan guru yang diperlukan pada era revolusi industri 4.0 dalam mendidik siswa SD pada pembelajaran matematika. Hasil yang didapatkan oleh para guru dapat mereka terapkan pada pembelajaran. Melalui kegiatan ini pula diharapkan dapat menciptakan para siswa yang siap menghadapi tantangan pada era revolusi industri 4.0.

Peneliti menyarankan bagi guru yang telah mendapatkan pelatihan diharapkan mampu menerapkan ilmu yang sudah di dapat dari kegiatan Training of Teachers (ToT) sehingga dapat menciptakan para siswa yang siap menghadapi tantangan pada era revolusi industri 4.0. Selain itu, bagi pembaca dapat menjadi referensi baru terkait menjadi guru yang memiliki kecakapan dalam kebutuhan era revolusi industri 4.0.

\section{DAFTAR PUSTAKA}

Astini, N. K. (2019). Pentingnya Literasi Teknologi Informasi Dan Komunikasi Bagi Guru Sekolah Dasar Untuk Menyiapkan Generasi Milenial. Prosiding Seminar Nasional Dharma Acarya ke-1 Tantangan dan Peluang Dunia Pendidikan di Era 4.0 - 13 Juli 2019, 113-120

Buku Pedoman Progran Gernas Tastaka. PT Bukit Asam Tbk-Mahasiswa .

Lase, D. (2014). Pendidikan di Era Revolusi Industri 4.0. Jurnal Sundermann, 1(1), 2843.

Miarso, Y. (2008). Peningkatan Kualifikasi Guru. Jurnal Pendidikan Penabur(10), 6676.

Pribowo, F. (2017). analisis kemampuan guru sd terhadap teknologi informasi dan komunikasi. else (elementary school education journal), 1(1), 11-25.

Putra, Z. (2019). Tantangan dan peluang guru sd dalam pembelajaran matematika berbasis teknologi digital di era revolusi industri 4.0. Prosiding seminar nasional pendidikan guru sekolah dasar fakultas keguruan dan ilmu pendidikan universitas riau, 7-19.

Shaumi, A. (2015). Pendidikan Kecakapan Hidup (Life Skill) Dalam Pembelajaran Sains Di Sd/Mi. Jurnal Pendidikan dan Pembelajaran Dasar, 2(2), 240-252.

Somantri, D. (2021). Abad 21 Pentingnya Kompetensi Pedagogik Guru. Equilibrium: Jurnal Penelitian Pendidikan dan Ekonomi, 18(2), 188-195.

Suparto, H. B. (2016). Peran guru sd dalam membangun karakter dan kecakapan di abad 21. Prosiding seminar nasional: "Optimalisasi Peran Pendidikan dalam Membangun Karakter Anak untuk menyongsong Generasi Emas Indonesia”, 195201. 
Syahrudin. (2020). Menimbang Peran Teknologi dan Guru dalam Pembelajaran di Era COVID-19.

Wati, I. \&. (2019). Pentingnya guru professional dalam mendidik siswa milenial untuk menghadapi revolusi 4.0. Prosiding seminar nasional pendidikan program pascasarjana universitas pgri palembang 12 januari 2019 , 364-370 